\title{
PRODUCTION CYCLE TIME REDUCTION IN LOW AND MEDIUM-LOW-TECH COMPANIES: A CASE STUDY FOR SERBIA
}

\author{
Milivoj Klarin, Vesna Spasojević Brkić, Tamara Golubović, Sanja Stanisavljev, Aleksandar Brkić, \\ Zvonko Sajfert
}

Original scientific paper

Serbia is a developing country, which among other things implies underdeveloped industrial base. A fact is that more than two thirds of all Serbian industry includes low-tech and medium-low-tech companies. These companies should implement tools and methods that are simple and low cost, but effective and helpful in a way that will increase their productivity and product quality. This paper suggests such a method for obtaining production cycle time components, and verifies it through a case study conducted during three years in one Serbian company. Practical result of this research is that application of the proposed method leads to reducing production cycle time, increasing production time, increasing production and increasing overall satisfaction and engagement of the executor.

Keywords: low and medium-tech companies; production cycle; time components of production cycle

Smanjenje vremena proizvodnog ciklusa kod tvrtki na niskom i srednje-niskom tehnološkom stupnju: studija slučaja za Srbiju

Izvorni znanstveni članak

Srbija je zemlja u razvoju, što između ostalog podrazumijeva nerazvijenu industrijsku bazu. Činjenica je da više od dvije trećine svih Srpskih industrija uključuje tvrtke na niskom i srednje niskom tehnološkom stupnju. Te tvrtke trebaju implementirati alate i metode koji su jednostavni i zahtijevaju male troškove, ali su učinkoviti i korisni u smislu da će povećati produktivnost i kvalitetu proizvoda. Ovaj članak predlaže jednu takvu metodu za dobivanje vremenskih komponenti proizvodnog ciklusa i provjerava njenu učinkovitost kroz studiju slučaja provedenu tijekom tri godine u jednoj srpskoj tvrtki. Praktični rezultat ovog istraživanja je da primjena predložene metode dovodi do smanjenja vremena proizvodnog ciklusa, povećanja proizvodnog vremena, povećanja proizvodnje i povećanja ukupnog zadovoljstva i angažmana izvršitelja.

Ključne riječi: proizvodni ciklus; tvrtke na niskom i srednje niskom tehnološkom stupnju; vremenske komponene proizvodnog ciklusa

\section{Introduction}

Serbia is a developing country, which among other things implies underdeveloped industrial base, and urgent need for improvement. It is clear that since Serbia is at the crossroads of structural changes, and for sustainable economic growth and stability of the country strong production is necessary, new concept of industrial policy is needed, which would be oriented to growth and innovations, rapid technological progress, new materials and advanced technologies, etc. [1].

However this process in practice is very difficult and very slow. The fact is that technological profile of Serbia's industrial structure comprises $49,9 \%$ of low-tech and $25,6 \%$ of medium-low-tech group [1]. That is, more than the two thirds of all industry is very far from implementing new materials and advanced technologies. These companies should, as a first step, find and implement tools and methods that are simple and low cost, but effective and helpful in a way that will increase productivity and product quality. In this way small and non-automated companies can introduce some improvements within their boundaries which would provide them more solid ground to move towards extreme structural changes.

Therefore the purpose of this study is to propose a new methodology, based on an established methodological approach work sampling [2], that can improve production process in a simple way and to prove benefits of its application by means of experimental research carried out during three years in one company. After each year data collected in the company were analysed and some changes were introduced in production process according to those analyses, to show, in the following years, that application of the method indeed provides production cycle time reduction.

Production system includes technological systems and other technical, information and energetic structures which in a certain way provide execution of the set goals of production process. In order to have uninterrupted production process, which is very important due to schedules and costs, it must be thoroughly planned. This implies detailed computation of machine operation durations and technological times given in advance. However operation time elements behave differently over time and implementation, especially with small and medium companies, so they can only be predicted rather than computed. That is why observing and monitoring of these elements is of great significance in production process.

Production cycle is defined as time required manufacturing a product part or series of product parts, from beginning of production process to their storage. Reduction of production cycle time can benefit production in company in many ways, including lower manufacturing costs, improved quality, reduced time to respond to market and customer demands, etc. These improvements in production can be crucial for survival and profitability of many companies.

Production cycle time $t_{\mathrm{pc}}$ is composed from several components, namely production time $t_{\mathrm{p}}$ and non-production time $t_{\text {np }}$. Also, production time is composed of technological time $t_{\mathrm{t}}$, with set-up time $t_{\mathrm{pt}}$ and manufacturing time $\mathrm{tm}$, and also of non-technological time $t_{\mathrm{nt}}$ with control time $t_{\mathrm{c}}$, transportation time $t_{\mathrm{tr}}$ and packaging time $t_{\mathrm{pk}}$. Non-production time is composed of various time components 
which cause production hold-ups, namely lack of raw materials $t_{\mathrm{mr}}$, organization factors, stoppage due to tools $t_{\mathrm{t} 1}$, machine breakdown $t_{\mathrm{b}}$ and other problems $t_{\mathrm{ot}}$ [3].

Duration of production cycle is one of the main economic and technical indicators of production process performance [4]. Hence, analyses of this process, its structure and duration, is a crucial part of economic and technical analyses of company operation. Duration of production cycle is tightly related to other indicators such as production volume, productivity, usability of production funds and working assets, etc. [5].

Production cycle is divided into two essentially different parts, as can be seen from definition above. First part $\left(t_{\mathrm{p}}\right)$ includes actual operating with the material or product part, while second part $\left(t_{\mathrm{np}}\right)$ includes various interruptions of the first part. Therefore in manufacturing process it is preferable to reduce non production time as much as possible. Also within production time non technological time should be reduced to a minimum, because only technological time actually makes changes and transforms material or part.

Some of these time components within production cycle are independent of each other but some can be affected by changing others [6]. As their inter relationship is complex, it is very important to monitor all of them separately, and then analyse each component individually, rather than taking into account only product cycle time, as it is commonly done in practice. Also this issue rarely appears in literature $[7 \div 11]$.

Methodology proposed in this paper provides simple and low cost way to obtain the mentioned production cycle time components, and in that way enables identification of individual time component causes, so that afterwards those causes can be affected on.

Research was carried out in a Serbian car cable company with small scale production. This company is a good representative of the type of Serbian companies mentioned earlier, since it is small, non-automatized, with relatively old equipment, lack of fund for large investments, but still working and manufacturing and sustaining in these conditions. As such it was perfect for application of the method that is suggested in this paper as well as for verification of the method. Verification was done by introducing improvements based on obtained results and afterwards monitoring how those improvements affected results in the following years.

After the introduction in Section 1, Section 2 presents the methodology to determine the elements of production cycle time while Section 3 gives results derived from three years experimental research conducted in order to verify the proposed method. Section 4 presents the discussion about benefits that application of the method can provide to small and non-automatized companies and Section 6 offers the conclusions.

\section{Material and methods}

Monitoring the working time elements can be done with the work sampling method which was first introduced by Tippet $[12,13]$. Originally work sampling is a technique of getting idea about capacities utilization levels of machines through a large number of instantaneous observations taken at random time intervals. However only three elements are observed, namely machine is operating, machine is not operating and machine is in preparation. Authors of present paper modified this method $[14,15]$ by dividing the observed elements into more components than Tippet had, which provided more details about process and showed that capacities utilization is a stochastic function via control limits that are optimal when defined by 2 standard deviations.

In present paper authors used modified work sampling method not for capacities utilization analysis but for production cycle analysis. Application of the method was verified as it was conducted during years of 2011, 2012 and 2013 in the aforementioned company in Serbia.

Screening is conducted according to randomly chosen times that are entered in a screening sheet. The screening sheet is related to one production cycle, and the numbers of individual elements of work, i.e. frequencies, are entered in it. Using the frequencies, the percentage of the individual elements against the total production cycle time is calculated, and then based on the production cycle time duration, analytically screened, the time duration of the individual elements of working time is calculated.

Monitoring of time elements was conducted during three years in the Serbian company. Monitoring took place in the last quarter of each year and lasted from 10 to 20 days, depending on production cycle duration. Number of cycles recorded varied each year, namely 46 in 2011, 30 in 2012 and 39 in 2013, and they had various numbers of product parts in each cycle.

After all data are obtained using the new method, they have to be analysed in order to determine where the main problems are, i.e. which components contribute most to the production cycle time. Some guidelines for reducing each component are given in [6]. For example, set-up time can be reduced by improving setup procedures or dedicating workstations to families of parts with similar set-up requirements. Manufacturing time reduction can be accomplished by reducing the number of operations required (by redesigning the part so that fewer operations are required) or reducing the processing time per operation (by dedicating labour to a family of parts with similar processing requirements), and so forth. Some of these guidelines were applied in present company after time components were obtained and analysed.

When improvements were introduced, time components had to be recorded in the following years in the same manner and results compared. For results to be comparable data had to be slightly transformed. As time components were obtained for different numbers of cycles and different numbers of product parts, it was necessary to express them in terms of time components per one part so that comparison between years would be adequate.

\section{Results}

\subsection{Simplification of data collection process}

Results from the first two years of research in car company showed that total percentages of time by cycles coincide with total percentages by frequencies, which means that it is unnecessary to measure duration of every time component in every cycle. 
Time components duration measured in minutes is different because of different duration of production cycles regarding frequency percentage, due to some cycles being shorter and some longer. In 2012 for 30 cycles, that were monitored and expressed with percentages of total duration of all cycles or in particular sum in minutes for each time element (which is also divided by total duration of all production cycles), the identical percentages were obtained or expressed in minutes, almost identical values per time elements were obtained.

Therefore there is no need for recording every time component individually in minutes. Differences among individual recordings, for the same frequencies percentages and durations of particular time elements, for 2012, are shown in table 1 for set-up time and manufacturing time.

Table 1 Manufacturing and set-up time for 2012

\begin{tabular}{|c|c|c|c|c|c|c|}
\hline \multirow{2}{*}{ Cycle } & \multirow{2}{*}{$\begin{array}{c}\text { Number of } \\
\text { observations }\end{array}$} & $t_{\mathrm{tc}}$ & $t_{\mathrm{pt}}$ & $t_{\mathrm{m}}$ & $t_{\mathrm{pt}}$ & $t_{\mathrm{m}}$ \\
\hline & & $\min$ & $f / \%$ & $f / \%$ & $\min$ & $\min$ \\
\hline 1 & 17 & 216 & 17,65 & 23,53 & 38,10 & 50,80 \\
\hline 2 & 17 & 216 & 11,76 & 29,41 & 25,40 & 63,50 \\
\hline 3 & 20 & 178 & 15,00 & 30,00 & 26,70 & 53,40 \\
\hline 4 & 22 & 178 & 18,18 & 27,27 & 32,40 & 48,50 \\
\hline 5 & 25 & 284 & 28,00 & 20,00 & 22,70 & 56,80 \\
\hline 6 & 26 & 240 & 41,54 & 19,23 & 27,70 & 46,20 \\
\hline 7 & 15 & 194 & 13,33 & 20,00 & 25,90 & 38,80 \\
\hline$\ldots$ & & & & & & \\
\hline 22 & 22 & 249 & 18,8 & 27,27 & 45,30 & 67,90 \\
\hline 23 & 23 & 304 & 21,74 & 30,43 & 66,10 & 92,50 \\
\hline & $\Sigma$ & 6978 & & & 1124 & 1737 \\
\hline & $\widehat{x}$ & 233 & 16,82 & 25,29 & 37 & 58 \\
\hline & SD & 33 & 6,51 & 6,52 & 15 & 13 \\
\hline
\end{tabular}

Hence, for equal number of recordings (22), equal frequency (4) and equal percentage $(18,8 \%$ ) for cycles 4 and 22 (Tab. 1) there is a different duration of set-up time (32,4 min for cycle 4 and 45,3 min for cycle 22). Even more significant difference can be seen for manufacturing time where for frequencies of 6 and percentages of 27,27 $\%$ time durations are 48,5 $\mathrm{min}$ i 67,9 $\mathrm{min}$.

During 2013 monitoring was conducted in such a way that only frequencies of time components appearance were noted and results are shown in table 2 together with calculated percentages and durations of particular time elements.

\section{Production cycle time components obtained by new method for 2013}

Tab. 2 shows that there were 39 cycles recorded in 2013, and number of observations varied between 17 and 28 with average being 20,87. Average duration of production cycles that were recorded analytically was 248 minutes.

Within production time manufacturing time has the most significant percentage, $23,76 \%$. Next is set-up time with $16,15 \%$, which together with manufacturing time makes technological time with $39,91 \%$. Average production time in 2013 was $p=193$ min $(79,77 \%)$ and nonproduction time $t_{\mathrm{np}}=54,8(20,36 \%)$.

Trend of time components percentages of all 39 cycles is given through polygons in diagram showed in Fig. 1. Area between two lines presents size of time components. It can be noticed that there are no big oscillations among cycles which indicates that the process is under control.

\subsection{Production cycle reduction from 2011 to 2113}

Tab. 3 shows summary results about production cycle time components from 2011 and 2013. Tab. 4 shows, on example of production time from 2013, how production time per one product part is obtained. The cycles with equal number of product parts were separated by groups along with their production times, and for each group the average of production time was calculated. Then the sum of calculated production time was divided by number of the groups which resulted in production time per one product part. Tab. 5 is obtained from Tabs. 3 and 4 , and it shows production cycle time components per one product part. This table is used to compare results from 2011 and 2013.

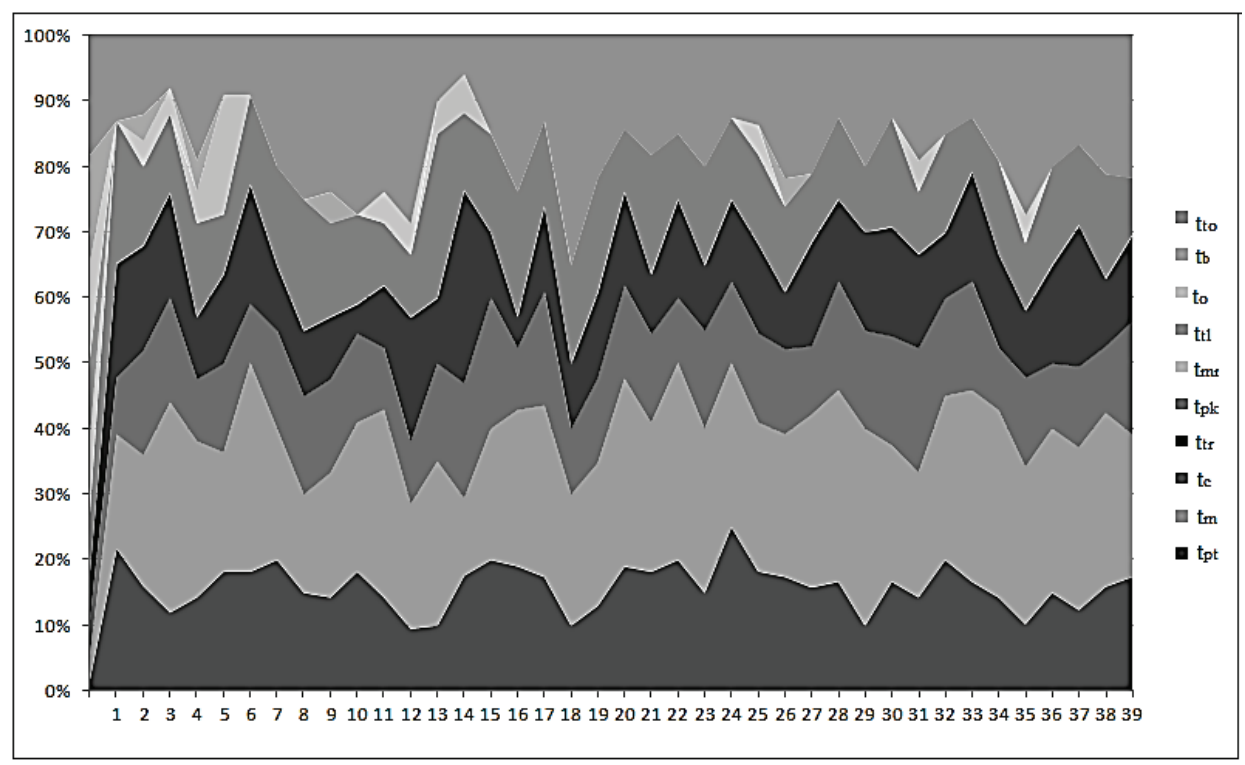

Figure 1 Diagram of trend of time components percentages 
Table 2 Production cycle time components in 2013

\begin{tabular}{|c|c|c|c|c|c|c|c|c|c|c|c|}
\hline \multirow{2}{*}{\multicolumn{2}{|c|}{ Cycle }} & 1 & 2 & 3 & 4 & , & 37 & 38 & 39 & \multirow{4}{*}{$\%$} & \multirow{4}{*}{$\min$} \\
\hline Date & & 15.10 .2013$. & 15.10.2013. & 16.10.2013. & 16.10.2013. & $\ldots$. & 18.11.2013. & 19.11.2013. & 20.11 .2013 & & \\
\hline \multicolumn{2}{|c|}{ Time } & $\begin{array}{l}8: 08- \\
10: 50 \\
\end{array}$ & $\begin{array}{l}8: 36- \\
12: 00\end{array}$ & $7: 43-11: 20$ & $6: 27-11: 10$ &, & $\begin{array}{l}7: 00- \\
10: 40 \\
\end{array}$ & $\begin{array}{l}7: 40- \\
10: 40 \\
\end{array}$ & $\begin{array}{l}7: 50- \\
11: 40 \\
\end{array}$ & & \\
\hline \multicolumn{2}{|c|}{$t_{\mathrm{pc}} / \min$} & 162 & 204 & 217 & 283 &, & 220 & 180 & 230 & & \\
\hline \multirow[b]{2}{*}{$t_{\mathrm{pt}}$} & $\%$ & 21,7 & 16 & 12 & 14,3 &, & 13,6 & 15,8 & 17,4 & 16,15 & 1560,4 \\
\hline & $f$ & 5 & 4 & 3 & 3 & , & 3 & 3 & 4 & & \\
\hline \multirow[b]{2}{*}{$t_{\mathrm{tn}}$} & $\%$ & 17,4 & 20 & 32 & 23,8 &, & 27,2 & 26,3 & 21,7 & 23,76 & 2295,7 \\
\hline & $f$ & 4 & 5 & 8 & 5 & , & 6 & 5 & 5 & & \\
\hline \multirow[b]{2}{*}{$t_{\mathrm{c}}$} & $\%$ & 8,7 & 16 & 16 & 9,5 &,, & 13,6 & 10,2 & 17,4 & 13,37 & 1291,8 \\
\hline & $f$ & 2 & 4 & 4 & 2 &, & 3 & 2 & 4 & & \\
\hline \multirow{2}{*}{$t_{\mathrm{tr}}$} & $\%$ & 17,4 & 16 & 16 & 9,5 &,,, & 23,6 & 10,2 & 13 & 12,25 & 1183,6 \\
\hline & $f$ & 4 & 4 & 4 & 2 &, & 3 & 2 & 3 & & \\
\hline \multirow{2}{*}{$t_{\mathrm{pk}}$} & $\%$ & 21,7 & 12 & 12 & 14,3 &,,, & 13,6 & 15,8 & 8,7 & 14,1 & 1362,3 \\
\hline & $f$ & 5 & 3 & 3 & 3 &, & 3 & 3 & 2 & & \\
\hline \multirow{3}{*}{$t_{\mathrm{p}}$} & $f$ & 20 & 20 & 22 & 15 &, & 18 & 15 & 18 & \multirow{3}{*}{$t_{\mathrm{p}}=79,77$} & \multirow{3}{*}{$t_{\mathrm{p}}=7694$} \\
\hline & $\%$ & 80 & 80 & 88 & 71,4 &, & 81,8 & 78,9 & 78,3 & & \\
\hline & $\min$ & 129,6 & 163,2 & 191 & 202,1 &, & 180 & 142 & 180,1 & & \\
\hline \multirow[b]{2}{*}{$t_{\mathrm{mr}}$} & $\%$ & 0 & 0 & 0 & 4,8 & , & 0 & 0 & 0 & 0,99 & 95,7 \\
\hline & $f$ & 0 & 0 & 0 & 1 & , & 0 & 0 & 0 & & \\
\hline \multirow{2}{*}{$t_{\mathrm{tl}}$} & $\%$ & 0 & 0 & 0 & 0 & , & 0 & 0 & 0 & 0 & 0 \\
\hline & $f$ & 0 & 0 & 0 & 0 & , & 0 & 0 & 0 & & \\
\hline \multirow[b]{2}{*}{$t_{\mathrm{o}}$} & $\%$ & 0 & 4 & 4 & 0 & , & 0 & 0 & 0 & 0,68 & 65,7 \\
\hline & $f$ & 0 & 1 & 1 & 0 & , & 0 & 0 & 0 & & \\
\hline \multirow{2}{*}{$t_{\mathrm{b}}$} & $\%$ & 8 & 4 & 0 & 4,8 & , & 0 & 0 & 0 & 0,36 & 34,8 \\
\hline & $f$ & 2 & 1 & 0 & 1 & , & 0 & 0 & 0 & & \\
\hline \multirow{2}{*}{$t_{\mathrm{ot}}$} & $\%$ & 12 & 12 & 8 & 19 &, & 18,2 & 21 & 21,7 & 18,33 & 1771 \\
\hline & $f$ & 3 & 3 & 2 & 4 & , & 4 & 4 & 5 & & \\
\hline \multirow{3}{*}{$t_{\mathrm{np}}$} & $f$ & 5 & 5 & 3 & 6 & , & 4 & 4 & 5 & & \\
\hline & $\%$ & 20 & 20 & 12 & 28,6 &, & 18,2 & 21,1 & 21,7 & & \\
\hline & $\min$ & 32,4 & 40,8 & 26 & 80,9 &, & 40 & 38 & 49,9 & & \\
\hline$t_{\mathrm{pc}}$ & $f$ & 25 & 25 & 25 & 21 &, & 22 & 19 & 23 & $n=20,87$ & \\
\hline \multicolumn{2}{|c|}{$t_{\mathrm{pc}} / n(\min )$} & 23,1 & 34 & 24,1 & 47,2 &, & 36,7 & 25,7 & 23 & & \\
\hline \multicolumn{2}{|c|}{ Number of parts } & 7 & 6 & 9 & 6 & , & 6 & 7 & 10 & & \\
\hline
\end{tabular}

Inspecting Tab. 5 shows that technological time has been reduced by $26 \%$, and non-technological time by 34 $\%$. Non production time has been decreased by $43 \%$. This resulted in production cycles time reducing from 56 minutes per product part on to 37,67 minutes per product part, i.e. it has been reduced by $33 \%$.

Table 3 Summary results about production cycle time components

\begin{tabular}{|c|c|c|c|c|c|}
\hline \multirow{4}{*}{} & Year & \multicolumn{2}{|c|}{2011} & \multicolumn{2}{c|}{2013} \\
\cline { 2 - 6 } & No. of cycles & \multicolumn{2}{|c|}{46} & \multicolumn{2}{c|}{39} \\
\cline { 2 - 6 } & Units & $\%$ & $\min$ & $\%$ & min \\
\cline { 2 - 6 } & $t_{\mathrm{pt}}$ & 10,88 & 1632 & 16,1 & 1538 \\
\cline { 2 - 6 }$t_{\mathrm{p}}$ & $t_{\mathrm{m}}$ & 24,66 & 3698 & 23,68 & 2277 \\
\cline { 2 - 6 } & $t_{\mathrm{t}}$ & 35,54 & 5330 & 39,78 & 3815 \\
\cline { 2 - 6 } & $t_{\mathrm{c}}$ & 12,9 & 1935 & 13,55 & 1302 \\
\cline { 2 - 6 } & $t_{\mathrm{tr}}$ & 16,09 & 2413 & 13,17 & 1252 \\
\cline { 2 - 6 } & $t_{\mathrm{pk}}$ & 11,4 & 1709 & 13,65 & 1331 \\
\cline { 2 - 6 }$t_{\mathrm{np}}$ & $t_{\mathrm{nt}}$ & 40,39 & 6057 & 40,37 & 3885 \\
\cline { 2 - 6 } & $t_{\mathrm{mr}}$ & 2,63 & 394 & 0,99 & 99 \\
\cline { 2 - 6 } & $t_{\mathrm{tl}}$ & 0,27 & 40 & 0 & 0 \\
\cline { 2 - 6 } & $t_{\mathrm{o}}$ & 2,51 & 376 & 0,68 & 63 \\
\hline & $t_{\mathrm{b}}$ & 1,81 & 271 & 0,46 & 41 \\
\hline & $t_{\mathrm{ot}}$ & 16,86 & 2529 & 17,91 & 1777 \\
\cline { 2 - 6 } & $t_{\mathrm{p}}$ & 75,93 & 11387 & 80,15 & 7700 \\
\cline { 2 - 6 } & $t_{\mathrm{np}}$ & 24,08 & 3610 & 20,04 & 1980 \\
\cline { 2 - 6 } & $t_{\mathrm{pc}}$ & 100 & 14997 & 100 & 9680 \\
\hline
\end{tabular}

Regarding percentage contribution of each time component within production cycle time, Tab. 3 shows improvements compared to 2011. Within production time, contribution of technological time has been increased at the expense of non-technological time, which is a sign of improvement in production organization. Within production cycle time, production time percentage in 2011 was 75,93
$\%$ and non-production time $24,08 \%$. In 2013 this was improved as production time percentage increased to 80,15 $\%$ and non-production time accordingly decreased to 20,04 $\%$.

Table 4 Production time per one part from 2013

\begin{tabular}{|c|c|c|c|c|c|c|}
\hline Cycle & $t_{\mathrm{p}} / \%$ & $t_{\mathrm{p}} / \min$ & $\begin{array}{c}\text { No } \\
\text { of parts }\end{array}$ & $\begin{array}{c}t_{\text {ppercycl }} \\
\text { per part } \\
\text { min }\end{array}$ & $\begin{array}{c}t_{\mathrm{p}} \text { ser } \\
\% \%\end{array}$ & $\begin{array}{c}t_{\mathrm{p}} \text { per } \\
\text { part } \\
\text { min }\end{array}$ \\
\hline 11 & 71,4 & 200,6 & 4 & 50,2 & \multirow{4}{*}{77,0} & \multirow{4}{*}{47,0} \\
\hline 15 & 85 & 146,2 & 4 & 36,6 & & \\
\hline 23 & 80 & 208 & 4 & 52,0 & & \\
\hline 35 & 71,4 & 196,4 & 4 & 49,1 & & \\
\hline 9 & 71,4 & 184,2 & 5 & 36,8 & \multirow{8}{*}{79,9} & \multirow{8}{*}{36,7} \\
\hline 22 & 85 & 226,1 & 5 & 45,2 & & \\
\hline 24 & 87,5 & 188,1 & 5 & 37,6 & & \\
\hline 26 & 73,9 & 124,9 & 5 & 25,0 & & \\
\hline 27 & 78,9 & 165,7 & 5 & 33,1 & & \\
\hline 32 & 85 & 174,3 & 5 & 34,9 & & \\
\hline 34 & 77,3 & 204,8 & 5 & 41,0 & & \\
\hline 36 & 80 & 200 & 5 & 40,0 & & \\
\hline 2 & 80 & 163,2 & 6 & 27,2 & \multirow{9}{*}{79,4} & \multirow{9}{*}{33,7} \\
\hline 4 & 71,4 & 202,1 & 6 & 33,7 & & \\
\hline 7 & 80 & 176,8 & 6 & 29,5 & & \\
\hline 16 & 76,2 & 373,4 & 6 & 62,2 & & \\
\hline 17 & 87 & 217,5 & 6 & 36,3 & & \\
\hline 25 & 81,8 & 124,3 & 6 & 20,7 & & \\
\hline 29 & 80 & 124 & 6 & 20,7 & & \\
\hline 31 & 76,2 & 259,1 & 6 & 43,2 & & \\
\hline 37 & 81,8 & 180 & 6 & 30,0 & & \\
\hline 1 & 80 & 140,8 & 7 & 20,1 & \multirow{6}{*}{77,9} & \multirow{6}{*}{23,8} \\
\hline 6 & 90,9 & 200 & 7 & 28,6 & & \\
\hline 12 & 66,7 & 190,1 & 7 & 27,2 & & \\
\hline 18 & 65 & 178,1 & 7 & 25,4 & & \\
\hline 20 & 85,7 & 150 & 7 & 21,4 & & \\
\hline 38 & 78,9 & 142 & 7 & 20,3 & & \\
\hline
\end{tabular}


Table 4 Production time per one part from 2013 (continuation)

\begin{tabular}{|c|c|c|c|c|c|c|}
\hline Cycle & $t_{\mathrm{p}} / \%$ & $t_{\mathrm{p}} / \min$ & $\begin{array}{c}\text { No } \\
\text { of parts }\end{array}$ & $\begin{array}{c}t_{\text {ppercycl }} \\
\text { per part } \\
\text { min }\end{array}$ & $\begin{array}{c}t_{\mathrm{p}} \text { ser } \\
\%\end{array}$ & $\begin{array}{c}t_{\mathrm{p}} \text { per } \\
\text { part } \\
\text { min }\end{array}$ \\
\hline 5 & 72,7 & 166,5 & 8 & 20,8 & \multirow{6}{*}{79,8} & \multirow{6}{*}{27,1} \\
\hline 10 & 72,7 & 203,6 & 8 & 25,5 & & \\
\hline 13 & 85 & 208,3 & 8 & 26,0 & & \\
\hline 14 & 88,2 & 220,5 & 8 & 27,6 & & \\
\hline 19 & 78,3 & 327,3 & 8 & 40,9 & & \\
\hline 21 & 81,8 & 172,6 & 8 & 21,6 & & \\
\hline 3 & 88 & 191 & 9 & 21,2 & \multirow{3}{*}{83,5} & \multirow{3}{*}{22,3} \\
\hline 8 & 75 & 183,8 & 9 & 20,4 & & \\
\hline 28 & 87,5 & 227,5 & 9 & 25,3 & & \\
\hline 30 & 87,5 & 306,3 & 10 & 30,6 & \multirow{3}{*}{84,4} & \multirow{3}{*}{24,7} \\
\hline 33 & 87,5 & 253,8 & 10 & 25,4 & & \\
\hline 39 & 78,3 & 180,1 & 10 & 18,0 & & \\
\hline
\end{tabular}

Table 5 Production cycle time components per one product part

\begin{tabular}{|c|c|c|c|}
\hline & Year & 2011 & 2013 \\
\hline & Number of cycles & 46 & 39 \\
\hline & Units & $\min$ & $\min$ \\
\hline \multirow{7}{*}{$\begin{array}{c}t_{\mathrm{p}} \\
\text { per } \\
\text { part }\end{array}$} & $t_{\mathrm{pt}}$ & 6,14 & 5,98 \\
\hline & $t_{\mathrm{m}}$ & 13,9 & 8,86 \\
\hline & $t_{\mathrm{t}}$ & 20,04 & 14,84 \\
\hline & $t_{\mathrm{c}}$ & 7,27 & 5,07 \\
\hline & $t_{\mathrm{tr}}$ & 9,07 & 4,87 \\
\hline & $t_{\mathrm{pk}}$ & 6,42 & 5,18 \\
\hline & $t_{\mathrm{nt}}$ & 22,76 & 15,12 \\
\hline \multirow{8}{*}{$\begin{array}{l}t_{\mathrm{np}} \\
\text { per } \\
\text { part }\end{array}$} & $t_{\mathrm{mr}}$ & 1,48 & 0,39 \\
\hline & $t_{\mathrm{tl}}$ & 0,15 & 0 \\
\hline & $t_{\mathrm{O}}$ & 1,41 & 0,25 \\
\hline & $t_{\mathrm{b}}$ & 1,02 & 0,16 \\
\hline & $t_{\mathrm{ot}}$ & 9,51 & 6,91 \\
\hline & $t_{\mathrm{p}}$ & 42,8 & 30,7 \\
\hline & $t_{\mathrm{np}}$ & 13,57 & 7,7 \\
\hline & $t_{\mathrm{pc}}$ & 56 & 37,67 \\
\hline
\end{tabular}

\section{Discussion and conclusion}

The most significant result from the first two years of research in a Serbian car company is that it is not necessary to measure production cycle time components in minutes, that is, there is no need to record duration of every component individually, but instead it is sufficient to note the frequency of their appearance. Based on those frequencies, when sample is large enough, it is possible to calculate all other data needed. This conclusion makes data collection process shorter which makes the proposed method even more simple and efficient. With classic work sampling method this problem was not analysed. Furthermore, correctly done practical application of work sampling method was not supported with adequate mathematical analysis, so later on few modifications were proposed $[14 \div 16$,], which implied that capacity utilization level is monitored by days as process which for the sum of most relevant operation time elements and machine hold-ups is normally distributed.

Results presented in table 5 clearly showed that all time components were reduced in 2013 as a result of application of proposed method. Simple and low cost method for obtaining time components of production cycle provided detailed review of production cycle which enabled proper measures to be taken in order to reduce each time component and resulted in reducing production cycle time per one product part by one third, which is a very satisfying result.
Therefore, practical result of this research is that the application of simplified method for obtaining production cycle time components after analysing of results leads to:

- Reducing the production cycle time

- Increasing percentage of production time

- Increased production

- Increased overall satisfaction and engagement of executor.

As mentioned earlier, Serbia is struggling for its way to industrial development, and that way will be difficult and slow. This is especially the case with small, nonautomated companies that make a large part of industry in Serbia. Such companies can benefit from the method proposed in this paper because it is acceptable from both economic and complexity point of view and provides a simple way to improve production process, leading to other improvements.

Future work regarding this matter should be pointed out in a direction of finding more methods similar to the one proposed here which can help the low and lowmedium-tech companies to survive in the environment of developing countries.

\section{Acknowledgements}

This work is supported by a grant from the Serbian Ministry of Education and Science project TR 35017.

\section{References}

[1] Metal unions initiatives for sustainable industrial policy of Serbia, Towards Sustainable Industrial Policies in SEE Seminar, 14-16 September, Zagreb, 2011.

[2] Barnes, R. Work Sampling. 2nd ed. New York: Wiley, 1957.

[3] Čala, I.; Klarin, M.; Radojčić, M. Development of a Stohastic model for determing the elements of production cycle time and their optimization for serial production in metal processing industry and recycling processes. // International Symposium Engineering Management and Competitiveness. // Technical faculty "M. Pupin", Zrenjanin, Serbia, 2011, pp. 21-24.

[4] Jovanovic, J. R.; Milanovic, D. D.; Djukic, R. D. Manufacturing Cycle Time Analysis and Scheduling to Optimize Its Duration. // Strojniski vestnik-Journal of Mechanical Engineering. 60, 7-8(2014), pp. 512-524. DOl: 10.5545/sv-jme.2013.1523

[5] Jovanović, T. M.; Milanović, D. D.; Spasojević, V. K. Savremena organizacija i upravljanje proizvodnjom. Beograd: Mašinski fakultet, 1996.

[6] Johnson, D. J. A framework for reducing manufacturing throughput time. // Journal of Manufacturing Systems. 22, 4(2003), pp. 283-298. DOI: 10.1016/S0278-6125(03)80009-2

[7] Elnekave, M.; Gilad, J. Rapid video-based analysis for advanced work measurement. // Int. Journal of Production research. 44(2006), pp. 271-290. DOI: 10.1080/00207540500160920

[8] Niebel, W. B. Time Study. Handbook of Industrial Engineering, Salvendi G. ed., John Wiley \& Sons, 1982.

[9] Lee, Tzu-Hsien. Optimal production run length and maintenance schedule for a deteriorating production system. // The International Journal of Advanced Manufacturing. 43(2009), pp. 959-963. DOI: 10.1007/s00170008-1773-1 
[10] Giri, B. C.; Yun, W. Y. Optimal lot sizing for an unreliable production system under partial backlogging and at most two failures in a production cycle. // International Journal of Production Economics. 95(2005), pp. 229-243. DOI: 10.1016/j.jpe.2004.01.004

[11] Chung, K. J.; Hon, K. L.; Lan, S. P. The optimal production cycle time in an integrated production -inventory model for decaying raw materials. // Applied mathematical Modeling. 33, (2009), pp. 1-10. DOI: 10.1016/j.apm.2007.10.010

[12] Maynard, H. B. Industrial Engineering Handbook. Pittsburgh, PA: McGraw-Hill, 1971.

[13] Moder, J. J. Selection of work sampling observation times Part I : Stratified sampling. // AIIE Transactions. 12, (1980), pp. 23-31. DOI: 10.1080/05695558008974486

[14] Klarin, M. M.; Cvijanović, M. J. Spasojević-Brkić, K. V.The shift level of the utilization of capacity as the stochastic variable in work sampling. // International Journal of Production Research. 38, 12(2000), pp. 26432651. DOI: 10.1080/002075400411402

[15] Klarin, M. M.; Milanović, D. D.; Spasojević-Brkić, V.; Misita, M.; Jovanović, A. A. Method to assess capacity utilization in short cycle functional layouts. // Journal of Process Mechanical Engineering, Part E. 224, (2010), No E1.

[16] Salvendi, G. Industrial Engineering Handbook. John Wiley \& Sons, 1982 (1990).

\section{Authors' addresses}

\section{Milivoj Klarin, PhD, Professor}

University of Novi Sad, Technical faculty "Mihajlo Pupin", Đure Đakovića bb, 23000 Zrenjanin, Serbia

E-mail: mklarin@open.telekom.rs

Vesna Spasojević Brkić, PhD, Associate Professor

University of Belgrade, Faculty of Mechanical Engineering, Kraljice Marije 16, 11000 Beograd, Serbia

E-mail: vspasojevic@mas.bg.ac.rs

Tamara Golubović, MSc, Assistant

University of Belgrade, Faculty of Mechanical Engineering, Kraljice Marije 16, 11000 Beograd, Serbia

E-mail: tsedmak@mas.bg.ac.rs

\section{Sanja Stanisavljev, $M S_{C}$}

University of Novi Sad, Technical faculty "Mihajlo Pupin", Đure Đakovića bb, 23000 Zrenjanin, Serbia

E-mail:sanja@tfzr.uns.ac.rs

\section{Aleksandar Brkić, MSc}

University of Belgrade, Innovation Center, Faculty of Mechanical Engineering,

Kraljice Marije 16, 11000 Beograd, Serbia

\section{Zvonko Sajfert, PhD, Professor}

University of Novi Sad, Technical faculty "Mihajlo Pupin", Đure Đakovića bb, 23000 Zrenjanin, Serbia

E-mail: sajfertz@tfzr.uns.ac.rs 